\title{
Spatiotemporal Variability and Trends of Marine Heat Waves in the Red Sea over 38 Years
}

\author{
Bayoumy Mohamed ${ }^{1,2}\left(\mathbb{D}\right.$, Hazem Nagy ${ }^{1,3, *(\mathbb{D})}$ and Omneya Ibrahim ${ }^{1}(\mathbb{D}$ \\ 1 Oceanography Department, Faculty of Science, Alexandria University, Alexandria 21500, Egypt; \\ mohamedb@unis.no (B.M.); omneya.ibrahim@alexu.edu.eg (O.I.) \\ 2 Department of Arctic Geophysics, University Centre in Svalbard, 9171 Longyearbyen, Norway \\ 3 Marine Institute, Oranmore, Co Galway, Ireland \\ * Correspondence: hazem.nagy@marine.ie; Tel.: +353-(89)-985-494
}

Citation: Mohamed, B.; Nagy, H.; Ibrahim, O. Spatiotemporal Variability and Trends of Marine Heat Waves in the Red Sea over 38 Years. J. Mar. Sci. Eng. 2021, 9, 842. https:// doi.org/10.3390/jmse9080842

Academic Editor: Francisco Pastor Guzman

Received: 15 July 2021

Accepted: 1 August 2021

Published: 4 August 2021

Publisher's Note: MDPI stays neutral with regard to jurisdictional claims in published maps and institutional affiliations.

Copyright: (C) 2021 by the authors Licensee MDPI, Basel, Switzerland. This article is an open access article distributed under the terms and conditions of the Creative Commons Attribution (CC BY) license (https:// creativecommons.org/licenses/by/ $4.0 /)$.

\begin{abstract}
Marine heat waves (MHWs) can have catastrophic consequences for the socio-environmental system. Especially in the Red Sea, which has the world's second longest coral reef system. Here, we investigate the sea surface temperature (SST) variability and trends, as well as the spatiotemporal characteristics of marine heat waves (MHWs) in the Red Sea, using high resolution daily gridded $\left(1 / 20^{\circ}\right)$ SST data obtained from the Copernicus Marine Environment Monitoring Service (CMEMS) for the period 1982-2019. Results show that the average warming rate was about $0.342 \pm 0.047^{\circ} \mathrm{C} /$ decade over the entire Red Sea over the whole study period. The Empirical Orthogonal Function (EOF) analysis reveals that the maximum variability is over the central part of the Red Sea, while the minimum variability is in the southernmost part of the Red Sea. Over the last two decades (2000-2019), we have discovered that the average MHW frequency and duration increased by $35 \%$ and $67 \%$, respectively. The results illustrate that the MHW frequency and duration trends have increased by 1.17 counts/decade and 1.79 days/decade, respectively, over the study period. The highest annual MHW frequencies were detected in the years 2018, 2019, 2010, and 2017. A strong correlation $(\mathrm{R}=0.89)$ was found between the annual MHW frequency and the annual mean SST.
\end{abstract}

Keywords: Red Sea; marine heat wave; sea surface temperature; duration; frequency

\section{Introduction}

Heat waves are characterized as extended periods of unusually hot weather that have become more frequent and longer in recent decades, posing a threat to human health and ecosystems. A similar phenomenon known as a 'Marine Heat Wave' (MHW) has been observed in the oceans, endangering marine ecosystems and productivity [1-4]. The most recent definition of MHWs is discrete periods of abnormally warm sea surface temperatures that can last from five days to months above the 90th percentile threshold of SST climatology [5-7]. Despite extensive knowledge of global SST changes, the study and detection of MHWs and associated climate processes remains limited [2].

The Red Sea has a rich and diverse ecosystem [8]. It has the world's second longest coral reef system [9]. The importance of the Red Sea is highlighted by its high tourism volume and aquaculture, and also its relation to the gas and oil and fishing industries. Furthermore, the Red Sea is a hub for shipping activity, connecting European ports with China and Eastern Asia through Suez Canal.

The Red Sea has a negative water balance, which means that evaporation exceeds precipitation and combined river runoff $[10,11]$. It is considered to be an arid climate region with little precipitation and runoff, as there is a lack of any permanent rivers that flow into it [12-14].

The impact and consequences of MHW on Red Sea marine life are now critical for decision makers and stakeholders. There are no published MHW studies of the Red Sea. However, some studies in the Rea Sea have discovered a link between extreme heat events 
such as ocean heat waves and the spread of the El Nino-Southern Oscillation (ENSO) [15]. In addition, the authors have found several SST studies for the Red Sea region, addressing trends and changes in ocean surface temperature [16-27].

According to [21], the annual mean SST has changed from $27.4^{\circ} \mathrm{C}$ from 1985 to 1993 to $28.1^{\circ} \mathrm{C}$ from 1994 to 2007 , which was accompanied with significant warming in the mid-1990s. The authors of [15] discovered that the Red Sea maximum SST is warming at a rate of $0.17^{\circ} \mathrm{C} /$ decade, with the northern Red Sea alone warming from 0.4 to $0.45^{\circ} \mathrm{C}$ /decade from 1982 to 2015 , which exceeds the global trend of $0.11{ }^{\circ} \mathrm{C} /$ decade [15]. The amplification of recent summer warming and decadal variability of the Red Sea SST was studied in [25]. They found that the significant warming which began in the mid-1990s precisely corresponded with the onset of a positive phase of the Atlantic Multi-Decadal Oscillation (AMO) and a negative phase of the Silk Road Pattern (SRP) in 1997.

In this study, we have investigated the spatiotemporal characteristics and occurrence of MHWs in the Red Sea from 1982 to 2019 using high resolution SST OSTIA (Operational SST and Ice Analysis) data $\left(0.05^{\circ} \times 0.05^{\circ}\right)$. In addition, the SST spatial trend and variability were examined.

Section 2 describes the data and methodology of SST analysis. Section 3 reports the SST climatology, trend, and interannual variability. Section 4 shows the MHW results over the study period. Section 5 presents the discussion and Section 6 provides the conclusions.

\section{Data and Methods}

The Red Sea is an almost enclosed marginal tropical sea characterized by an extended shape that separates the African and Asian continents and is connected to the Indian Ocean through the Bab El-Mandab Strait, as shown in Figure 1. It has a moderate size of $4.5 \times 10^{6} \mathrm{~km}^{3}$, which is roughly one fifth the size of the Mediterranean Sea. The Bab ElMandeb strait, which connects the basin to the open ocean, is a small and shallow channel (sill depth of $160 \mathrm{~m}$ and the narrowest point is $25 \mathrm{~km}$ wide). The study area extending from $12.5^{\circ} \mathrm{N}$ to $30^{\circ} \mathrm{N}$ and from $32^{\circ} \mathrm{E}$ to $44^{\circ} \mathrm{E}$ has an average width of $\sim 220 \mathrm{~km}$ and a length of $\sim 2000 \mathrm{~km}$, with a maximum centered depth of $2200 \mathrm{~m}$ (Figure 1).

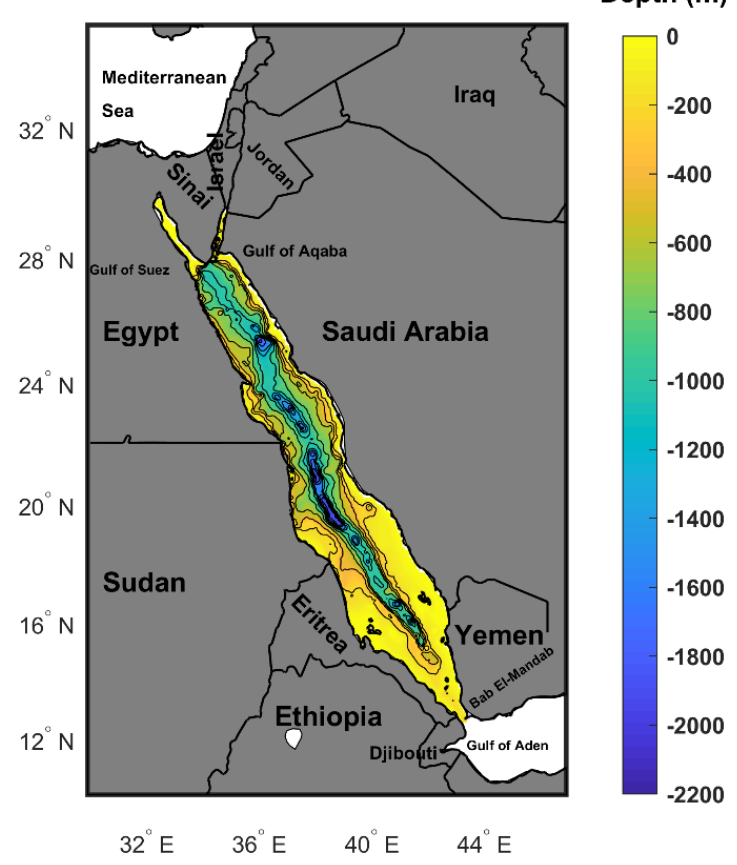

Figure 1. The Red Sea with the main geographic features (e.g., countries). The bathymetry is according to the GEBCO bathymetric dataset (www.gebco.net) (accessed on 15 April 2021), with a minimum depth of $10 \mathrm{~m}$. 


\subsection{Sea Surface Temperature Climatological Data}

The daily Sea Surface Temperature (SST) data used were freely obtained from the Copernicus Marine Environment Monitoring Service website (CMEMS) (https:/ / marine. copernicus.eu (accessed on 20 April 2021)) from 1 January 1982 to 31 December 2019. The data website is https://resources.marine.copernicus.eu/?option=com_csw\&view= details\&product_id=SST_GLO_SST_L4_REP_OBSERVATIONS_010_011 (accessed on 23 March 2021). The product name is 'SST_GLO_SST_L4_REP_OBSERVATIONS_010_011'. The CMEMS OSTIA (Operational SST and Ice Analysis) reprocessed analysis product is a satellite and in situ foundation SST analysis created by the OSTIA [28]. The SST dataset includes daily gap-free maps of sea surface temperature and ice concentration (known as the L4 product) with a horizontal grid resolution of $0.05^{\circ} \times 0.05^{\circ}$ [29]. CMEMS OSTIA data for the Red Sea were extracted from the global data, providing a 16534-point regularly gridded dataset spanning 13,879 days from 1 January 1982 to 31 December 2019.

\subsection{Trend and Interannual Variability of SST}

The Empirical Orthogonal Functions (EOFs) analysis [30] was used to evaluate the dominant spatiotemporal characteristics of SST variability from 1982 to 2019, utilizing the monthly de-seasonalized and detrended SST dataset to focus on non-seasonal variability. Thus, before decomposing the EOF, the seasonal cycle and linear trends were removed from the monthly means of SST anomalies at each grid cell, and each point time series was divided by its standard deviation to normalize the SST [31,32]. The mean seasonal cycle was estimated by calculating the mean monthly values for each calendar month at each grid point. SST anomalies were computed by removing the historical climatological mean value at each grid point from the SST values at the same location (grid). The strong seasonal signal was removed from the datasets at each grid cell to produce de-seasonalized maps and time series [33]. This was accomplished by subtracting the climatological mean of each calendar month from the corresponding months in all years. The least squares method [34] was used to estimate linear trends in de-seasonalized monthly sea surface temperature anomalies (SSTA). The Modified Mann-Kendall test $[35,36]$ was used to test the statistical significance of the trends. In this study, the significance level was set to $p \leq 0.05$, ensuring that all given trends are statistically significant at least at the $95 \%$ confidence level. The error of linear trend at the 95\% confidence level was calculated using [34] the formula which was mentioned in [37].

\subsection{Marine Heat Waves (MHWs) Calculations}

The authors of [5] used the "discrete prolonged anomalously warm-water events in a location" definition of MHWs, using the same daily SST dataset for the 1982-2019 period. The MATLAB toolbox [38] was used to detect periods of time where temperatures were above the 90th percentile threshold compared to the climatology (1982-2019), and with a duration of at least 5 days. The climatological mean has been calculated from the daily Sea Surface Temperature (SST) data from 1 January 1982 to 31 December 2019; the equations of MHW main characteristics are according to [5] and described in [7]. Daily SSTs were spatially averaged over the Red Sea $\left(12.5^{\circ}-30^{\circ} \mathrm{N}, 32^{\circ}-44^{\circ} \mathrm{E}\right)$ in our study to provide a regional daily SST time series spanning 1982-2019. In order to identify the MHWs in the Red Sea, the MHW definition was then applied to the SST time series.

Every MHW event has a start and end date defined by a mean ( $\left.i_{\text {mean }}\right)$ and a maximum intensity $\left(\mathrm{i}_{\max }\right)$ in ${ }^{\circ} \mathrm{C}$ (mean and spatiotemporal maximum temperature compared to the threshold over the MHW event duration (in days)), as described in [39]. The MHW cumulative intensity $\left(\mathrm{i}_{\text {cum }}\right)$ in ${ }^{\circ} \mathrm{C}$ days is defined as the spatiotemporal summation of daily temperature compared to the threshold over the event duration as mentioned by [39]. Following the methodology of $[4,40]$, the annual statistics were computed, including the frequency of events (i.e., the number of discrete events occurring each year). The MHW total number of days in each year can be used to examine how the frequency of occurrences in counts has changed over time, using the metrics for each location [5]. According to [5,7], 
the main characteristics of MHWs are maximum intensity $\left(\mathrm{i}_{\max }\right)$ in ${ }^{\circ} \mathrm{C}$, mean intensity ( $\left.\mathrm{i}_{\text {mean }}\right)$ in ${ }^{\circ} \mathrm{C}$, and cumulative intensity $\left(\mathrm{i}_{\text {cum }}\right)$ in $\left({ }^{\circ} \mathrm{C}\right.$ days):

$$
\begin{gathered}
\mathrm{i}_{\max }=\max \left(\mathrm{T}(\mathrm{t})-\mathrm{T}_{\mathrm{m}}(\mathrm{j})\right) \\
\mathrm{i}_{\text {mean }}=\overline{\mathrm{T}(\mathrm{t})-\mathrm{T}_{\mathrm{m}}(\mathrm{j})} \\
\mathrm{i}_{\text {cum }}=\int_{\mathrm{t}_{\mathrm{s}}}^{\mathrm{t}_{\mathrm{e}-1}}\left(\mathrm{~T}(\mathrm{t})-\mathrm{T}_{\mathrm{m}}(\mathrm{j})\right) d t
\end{gathered}
$$

where $T_{m}$ is the climatological OSTIA SST mean calculated over the period from 1 January 1982 to 31 December 2019, to which all values are relative; $j$ is the day of year; and $t_{s}$ and $t_{e}$ are the start and end dates of the MHW event, respectively.

\section{SST Climatology, Trend, and Interannual Variability}

Figure 2a depicts the temporal evolution of the daily mean climatology of Red Sea SST $\left({ }^{\circ} \mathrm{C}\right)$ from 1982 to 2019 . The highest temperatures $\left(>29^{\circ} \mathrm{C}\right)$ were in summer and early autumn (i.e., from July to October), while the lowest temperatures $\left(<25^{\circ} \mathrm{C}\right)$ were in winter and early spring (i.e., from January to March). The seasonal temperature difference between summer and winter is about $6{ }^{\circ} \mathrm{C}$, which is consistent with [22]. Figure $2 \mathrm{~b}$ shows the monthly de-seasonalized SST temporal trend over the study period. The higher deseasonalized SST values were noticed in the last 4 years of the study period (i.e., 2016-2019). The Red Sea temporal trend was about $0.32 \pm 0.03{ }^{\circ} \mathrm{C} /$ decade.

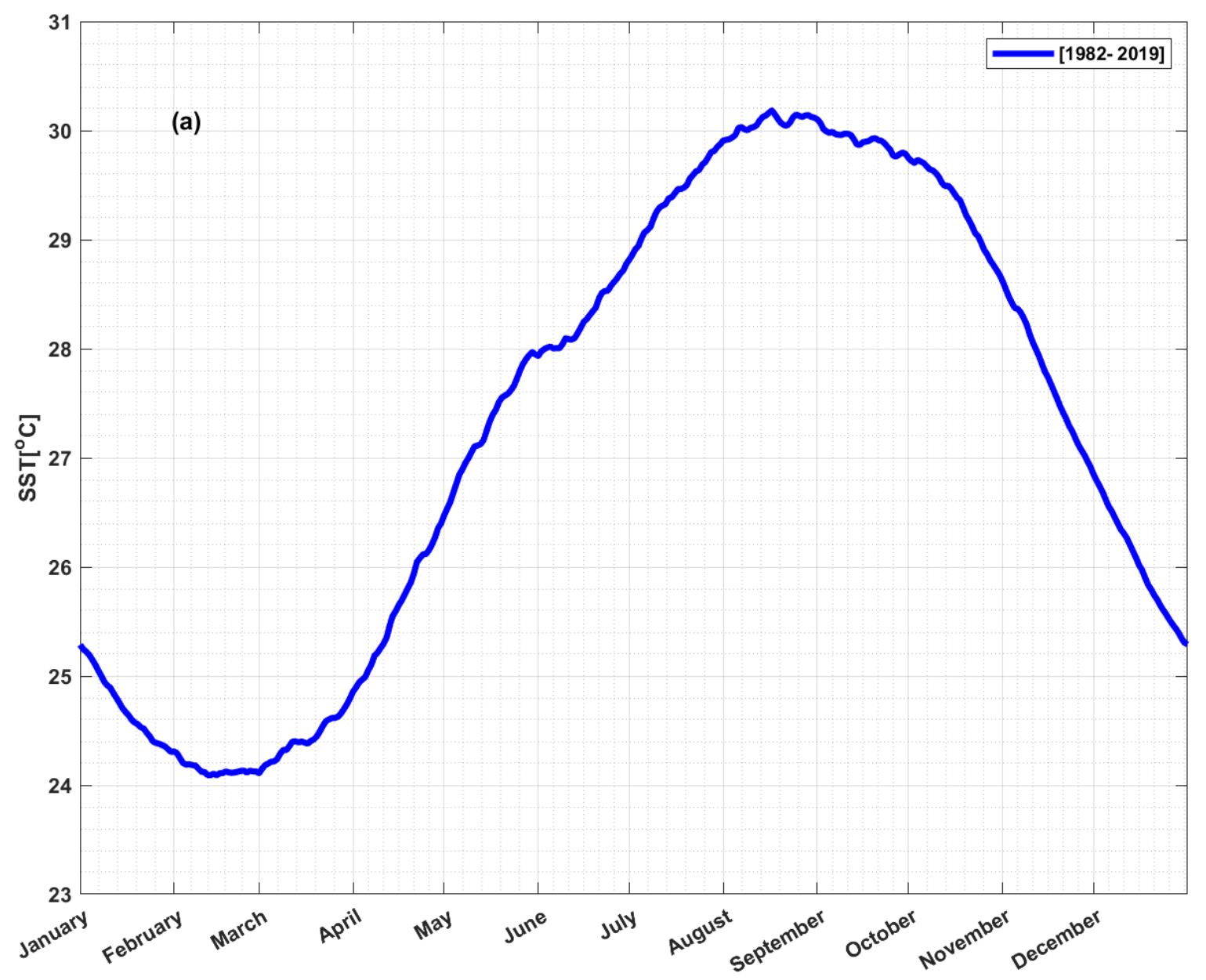

Figure 2. Cont. 


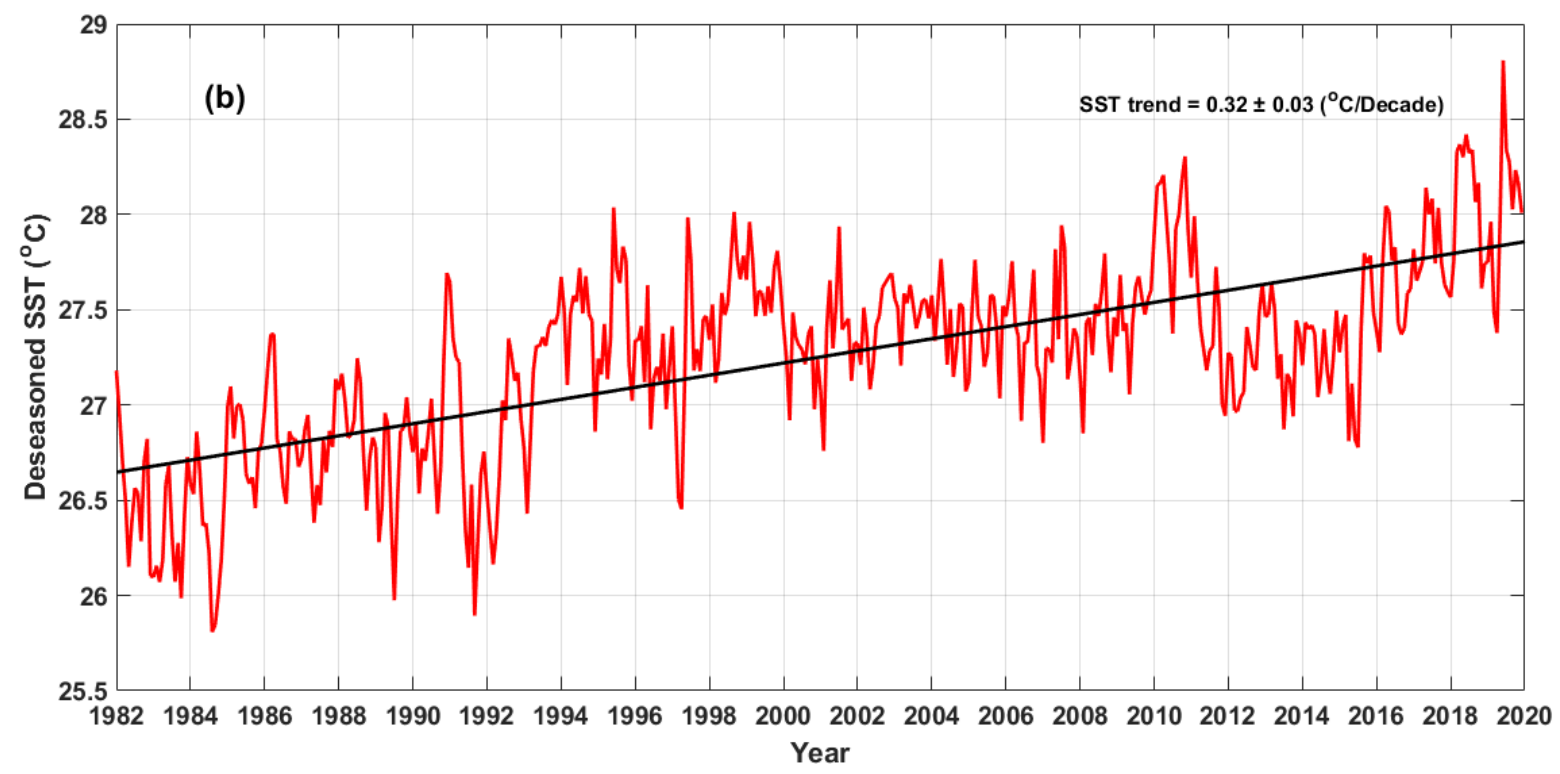

Figure 2. (a) The temporal evolution of the daily basin averaged SST (b) the de-seasonalized monthly SST time series (denoted by the continuous red line) and the SST trend (denoted by the continuous black line) from 1982 to 2019.

The spatial trend map of the de-seasonalized SSTA from 1982 to 2019 is shown in Figure 3. At the 95\% confidence interval, a statistically significant trend was observed over the entire region. The linear trend over the Red Sea is not uniform, varying from 0.1 to $0.47^{\circ} \mathrm{C} /$ decade. The basin averaged warming trend rate was about $0.342 \pm$ $0.047^{\circ} \mathrm{C} /$ decade. The highest trend was found in the deep area of the Red Sea (i.e., depth $>\sim 1200 \mathrm{~m}$ ), while lower values were found in the Gulfs of Suez and Aqaba and the southern part of the Red Sea.

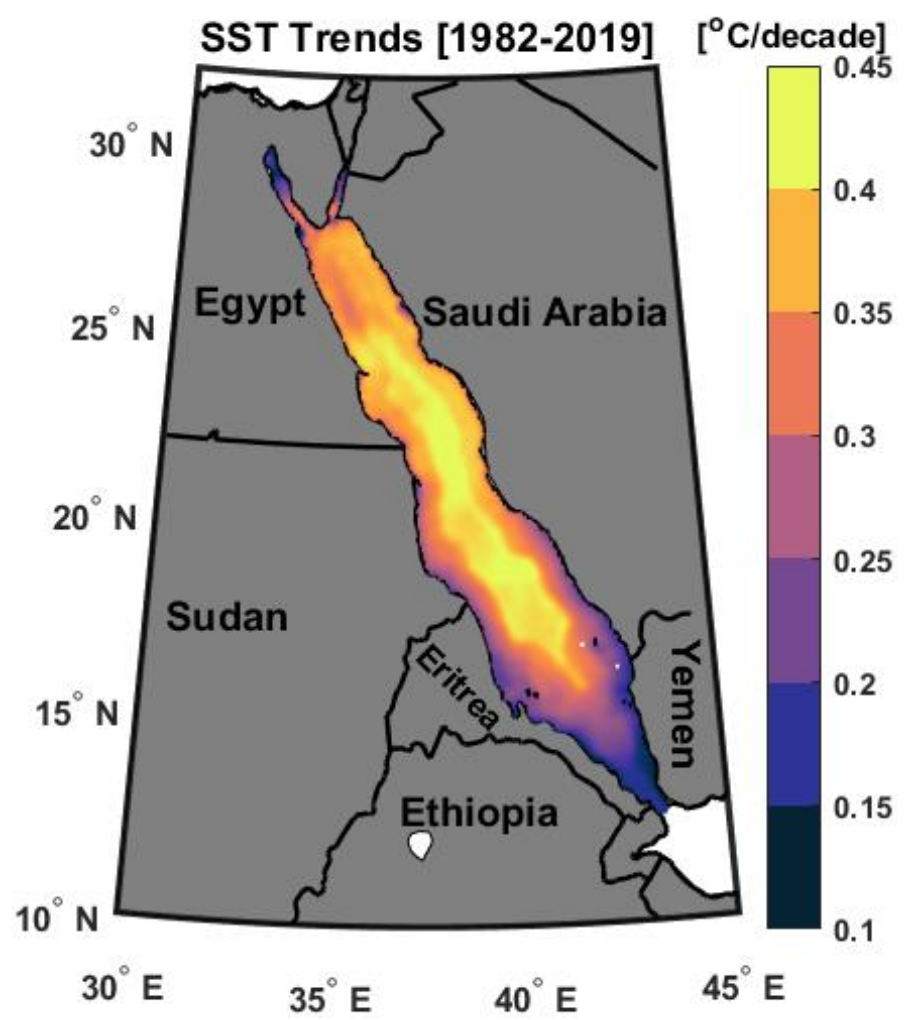

Figure 3. Spatial trend map of the Red Sea SST anomaly from 1982 to 2019, after the seasonal cycle was removed at each grid point. 
The first two EOF modes of SST account for $73 \%$ of the non-seasonal variance. The spatial pattern of the first EOF (EOF1) (accounting for approximately $52 \%$ of the nonseasonal variance) shows a positive anomaly over the entire Red Sea (Figure 4a), showing an in-phase oscillation. The highest variability was found over central and north part of Red Sea, while the lowest variability was detected over the Gulfs of Suez and the Aqaba and the southernmost region of the Red Sea. Strong and continuous northeasterly monsoon winds from the Arabian Sea redirected by mountains into southeasterly winds along the axis of the Red Sea [41] may have a thermal effect that is responsible for the lowest variability over the southern Red Sea. The lower variability in the Gulfs of Suez and Aqaba is due to strong northwesterly winds that penetrate the western edge of the Sinai Peninsula, blow southwards, and sometimes reach the southern end of the Red Sea. Its temporal coefficient PC1 shows a strong interannual variability, reaching its peak in the summers of 1995, 1997, and 2019. The highest negative peaks (i.e., cold periods) were observed in the winters of 1984, 1992, and 2015. The second mode (accounting for approximately $21 \%$ of the non-seasonal variance) is out-of-phase variability of the SST in the Red Sea, with positive anomaly values in the south and negative ones in the north. Over the study period of 1982-2019, the temporal coefficient of the second mode (PC2) fluctuates between positive and negative patterns.
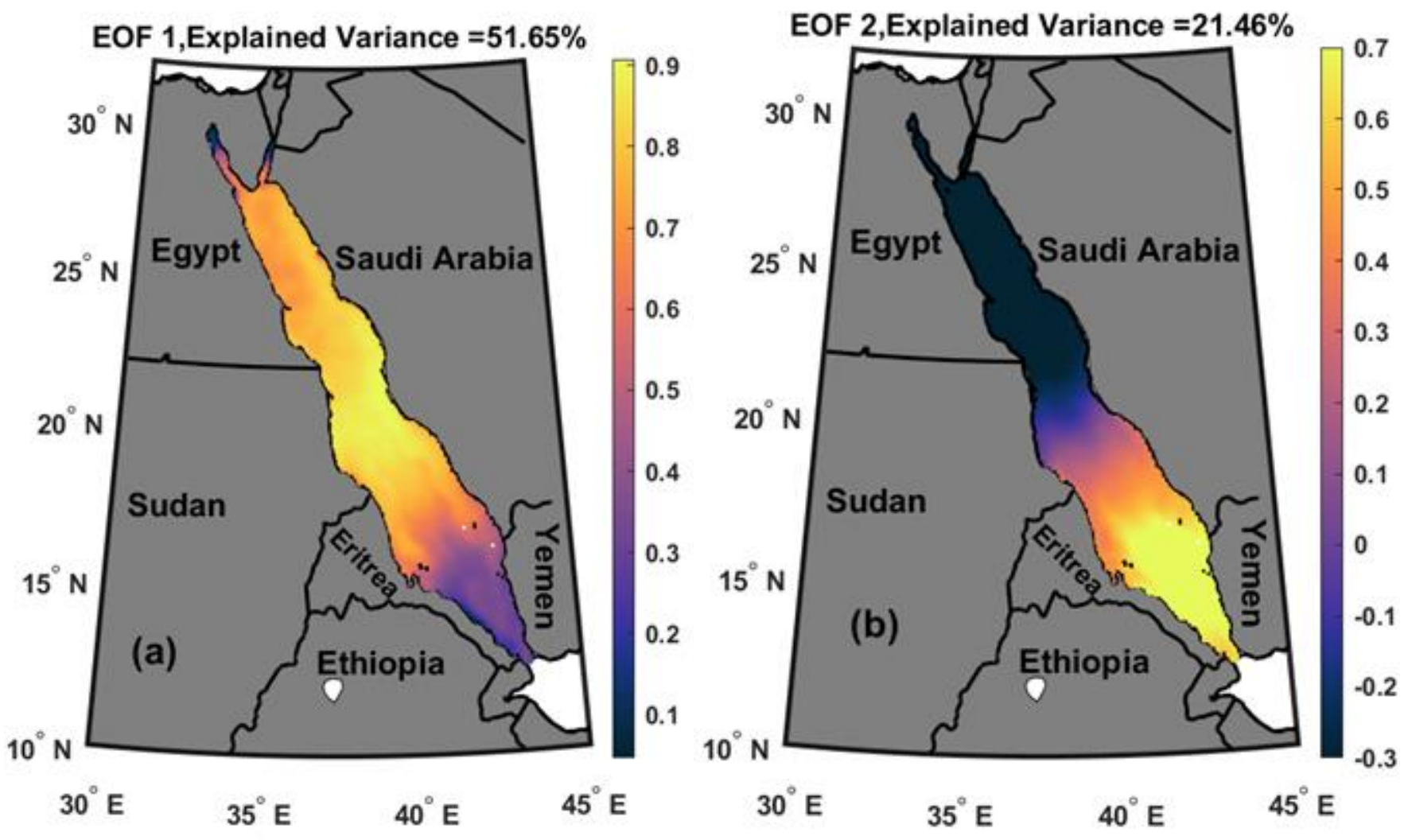

Figure 4. Cont. 

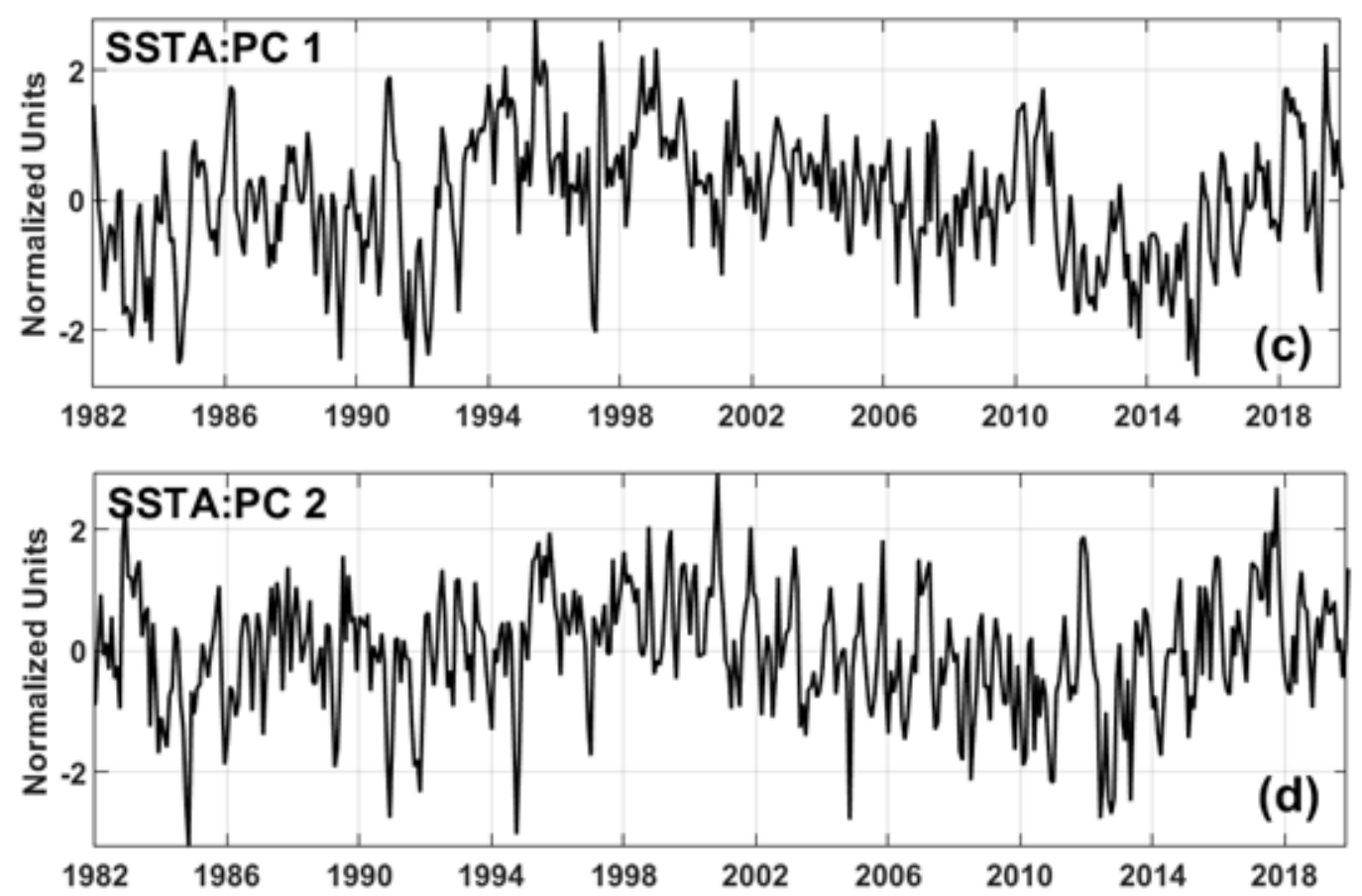

Figure 4. (a) Spatial distribution for the first EOF (EOF1); (b) Spatial distribution for the second EOF (EOF2); (c) Temporal evolution for EOF (PC1) in normalized variance units; (d) Temporal evolution for EOF (PC2) in normalized variance units; for the Red Sea SSTA over the period from 1982 to 2019.

\section{Main Characteristics and Trends of Marine Heat Waves (MHWs)}

The mean and spatial trend of the main characteristics of MHWs (frequency, days, duration, and intensities) over the entire study period are shown in Figure 5. The trend maps are superimposed with non-significant values $(p>0.05)$. Figure 5a demonstrates that the MHW frequency varied from 1 to 2.5 counts, with maximum values of $>2$ counts found in the coastal areas of Sudan, Eritrea, Yemen and Saudi Arabia. The MHW frequency trend values were statistically significant $(p<0.05)$ over the whole domain. The MHW frequency trend ranged between 0 and 2 counts/decade. The highest MHW frequency trend ( $>1.8$ counts/decade) was detected in the deep area (i.e., depth $>1000 \mathrm{~m}$ ) between Eritrea and south coast of Saudi Arabia, as shown in Figures 1 and 5b. The MHW total days spatial patterns in the study period (1982-2019) varied between 15 and 30 days, with maximum values of $>25$ days found inside the Gulfs of Suez and Aqaba (Figure 5c). This could be due to the Gulfs of Suez and Aqaba being well resolved with the high-resolution OSTIA data. In general, the northern Red Sea has higher values of MHW total days than the southern region. The MHW total days trend values were statistically significant $(p<0.05)$ across the whole domain (Figure 5d). We discovered a similarity among the $p$-values between the MHW frequency and total days trend fields (Figure 5b,d). The MHW mean duration ranged from 5 to 15 days, with maximum values of $>12$ days north of the Red Sea for the Gulfs of Suez and Aqaba (Figure 5e). The maximum MHW duration spatial trend significant values ( $p<0.05 ;>8$ days / decade) were found in the middle of the Red Sea (i.e., between lat $18^{\circ} \mathrm{E}$ and $21^{\circ} \mathrm{E}$ ) (Figure $5 \mathrm{f}$ ). Both the MHW duration and the $\mathrm{i}_{\text {cum }}$ spatial patterns revealed similarities between the two fields (Figure 5 e,g). The MHW $\mathrm{i}_{\text {cum }}$ values ranged from 10 to $25\left({ }^{\circ} \mathrm{C}\right.$ days), with maximum values of $>22\left({ }^{\circ} \mathrm{C}\right.$ days) north of the Red Sea, excluding the Gulfs of Suez and Aqaba (i.e., between $\sim$ lat $22^{\circ} \mathrm{E}$ and $28^{\circ} \mathrm{E}$ ) (Figure $5 \mathrm{~g}$ ). The maximum MHW $\mathrm{i}_{\text {cum }}$ significant trend values $\left(p<0.05 ;>10^{\circ} \mathrm{C}\right.$ days $/$ decade) were discovered in the same areas as the MHW duration trend (Figure 5f,h). The MHW $\mathrm{i}_{\max }$ showed values of $>1.8^{\circ} \mathrm{C}$ throughout most of the Red Sea except the southernmost part beside Bab El-Mandab (Figure 5i). The MHW maximum $\mathrm{i}_{\max }$ significant trend values $\left(p<0.05 ;>2.5^{\circ} \mathrm{C}\right)$ were found in the middle region of the Red Sea (i.e., between $\sim$ lat $19^{\circ} \mathrm{E}$ 
and $21^{\circ} \mathrm{E}$ ) and in the north of the Red Sea close to the Gulf of Suez (i.e., between $\sim$ lat $26^{\circ} \mathrm{E}$ and $28^{\circ}$ E) off the Egyptian coast (Figure 5j).
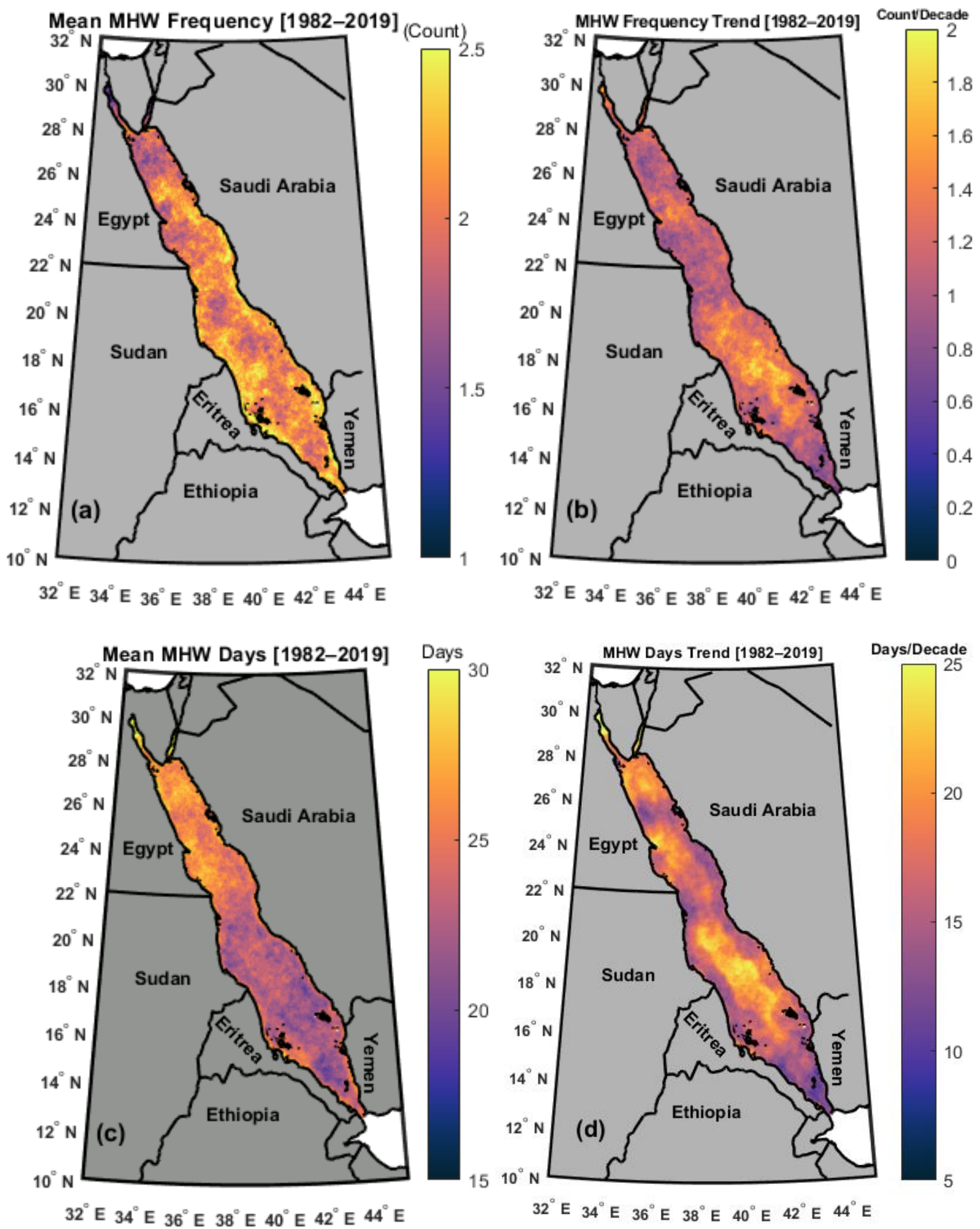

Figure 5. Cont. 

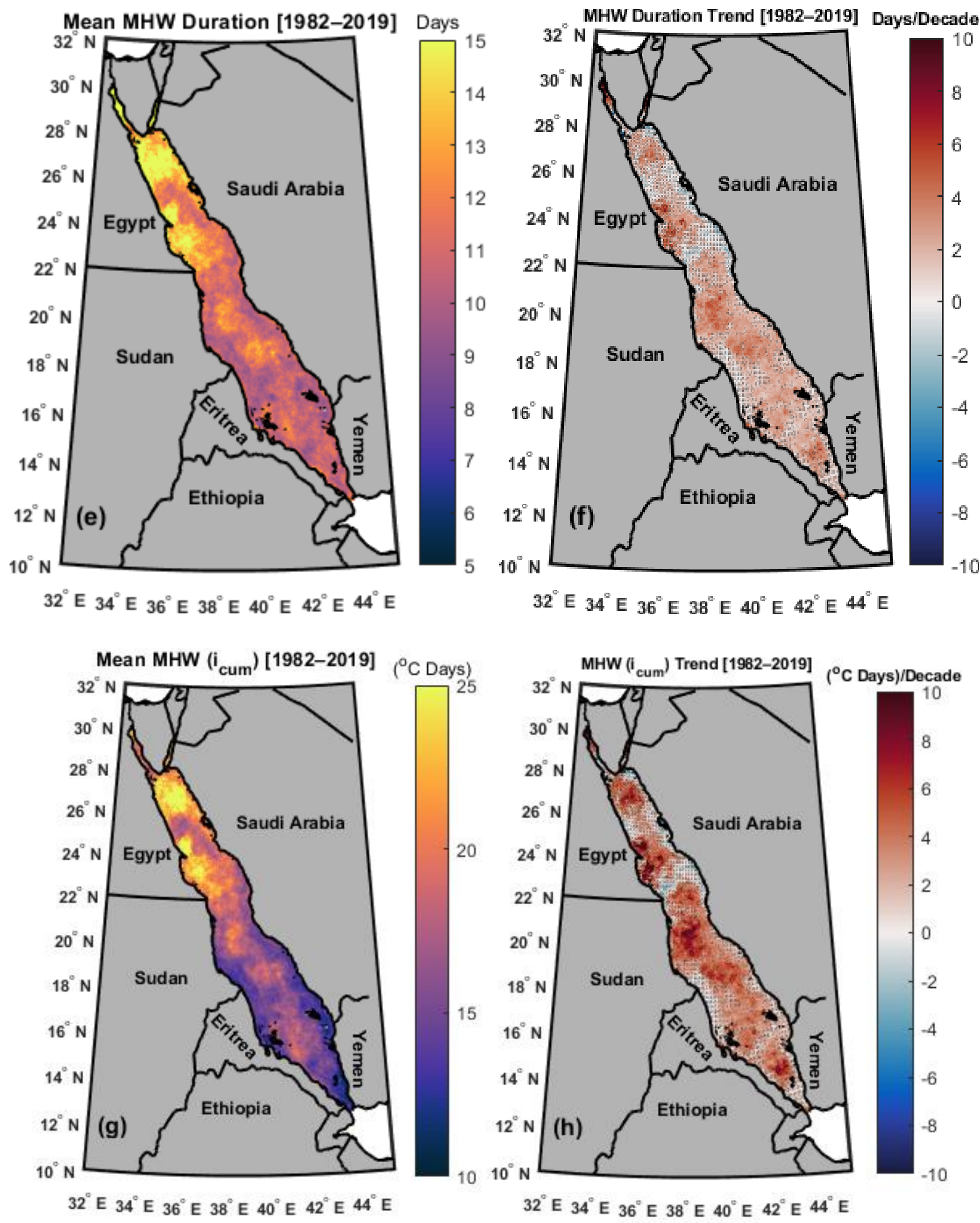

Figure 5. Cont. 

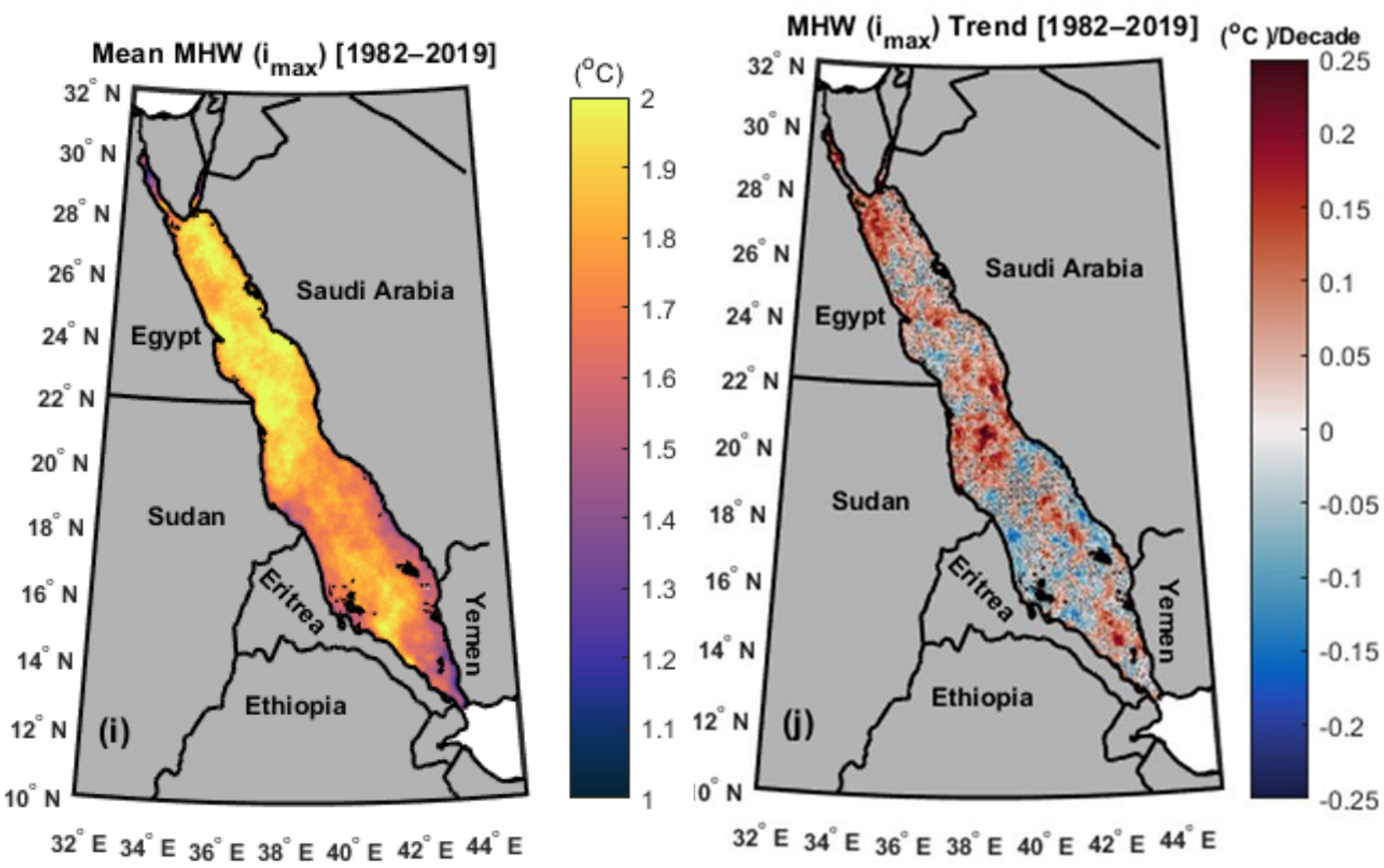

Figure 5. The main characteristics and trends of marine heat waves in the Red Sea over the study period (1982-2019) (a) mean MHW frequency (counts); (b) MHW frequency trend (counts/decade); (c) mean MHW total days (days); (d) MHW days trend (days/decade); (e) MHW duration (days); (f) MHW duration trend (days/decade); (g) $\mathrm{MHW}\left(\mathrm{i}_{\text {cum }}\right)\left({ }^{\circ} \mathrm{C}\right.$ days); (h) MHW ( $\left.\mathrm{i}_{\text {cum }}\right)$ trend $\left({ }^{\circ} \mathrm{C}\right.$ days $/$ decade); $(\mathbf{i})$ mean $\mathrm{MHW}\left(\mathrm{i}_{\max }\right)\left({ }^{\circ} \mathrm{C}\right) ;(\mathrm{j}) \mathrm{MHW}\left(\mathrm{i}_{\max }\right)$ trend $\left({ }^{\circ} \mathrm{C} /\right.$ decade); the black dots indicate that the change is not significantly different $(p>0.05)$.

\subsection{Marine Heat Waves (MHWs) Temporal Variation}

In this section, the authors present the temporal basin averaged annual MHW main characteristics (frequency, duration, and $i_{\text {cum }}$ ) from 1982 to 2019 . The goal was to investigate temporal changes in Red Sea MHW characteristics such as frequency, duration, and $i_{\text {cum }}$, as well as their relationship to SST (Figure 6). The MHW matrices for the Red Sea region show a clear ascending trend over the last decade, as shown in Figure 6.

From 1982 to 1994, the annual mean MHW frequency was <1, while from 1994 to 2019, the frequency of MHWs increased significantly, reaching a peak in 2018 (7 counts) (Figure 6a). These findings are consistent with the monthly SST time series shown in Figure 2b, from 1982 to 2019. We noticed that no MHWs were detected in 1984. We discovered a strong correlation $(R=0.89)$ between the annual mean SST and MHW frequency, (Figure 6b).

The results show a general rise in annual MHW duration from approximately 6 days to 21 days in 2018 (Figure $6 \mathrm{c}$ ), while $\mathrm{i}_{\text {cum }}$ ranged from $8{ }^{\circ} \mathrm{C}$ days to $30^{\circ} \mathrm{C}$ days (Figure 6e). The highest annual MHW duration and $\mathrm{i}_{\text {cum }}$ were found during $2018\left(\sim 21\right.$ days and $30^{\circ} \mathrm{C}$ days). We discovered that the average frequency and duration of MHWs increased by $35 \%$ and $67 \%$, respectively, over the last two decades (2000-2019).

The correlation coefficient between MHW duration and annual mean SST was 0.64, while the correlation coefficient between MHW $\mathrm{i}_{\text {cum }}$ and SST was 0.72 . 

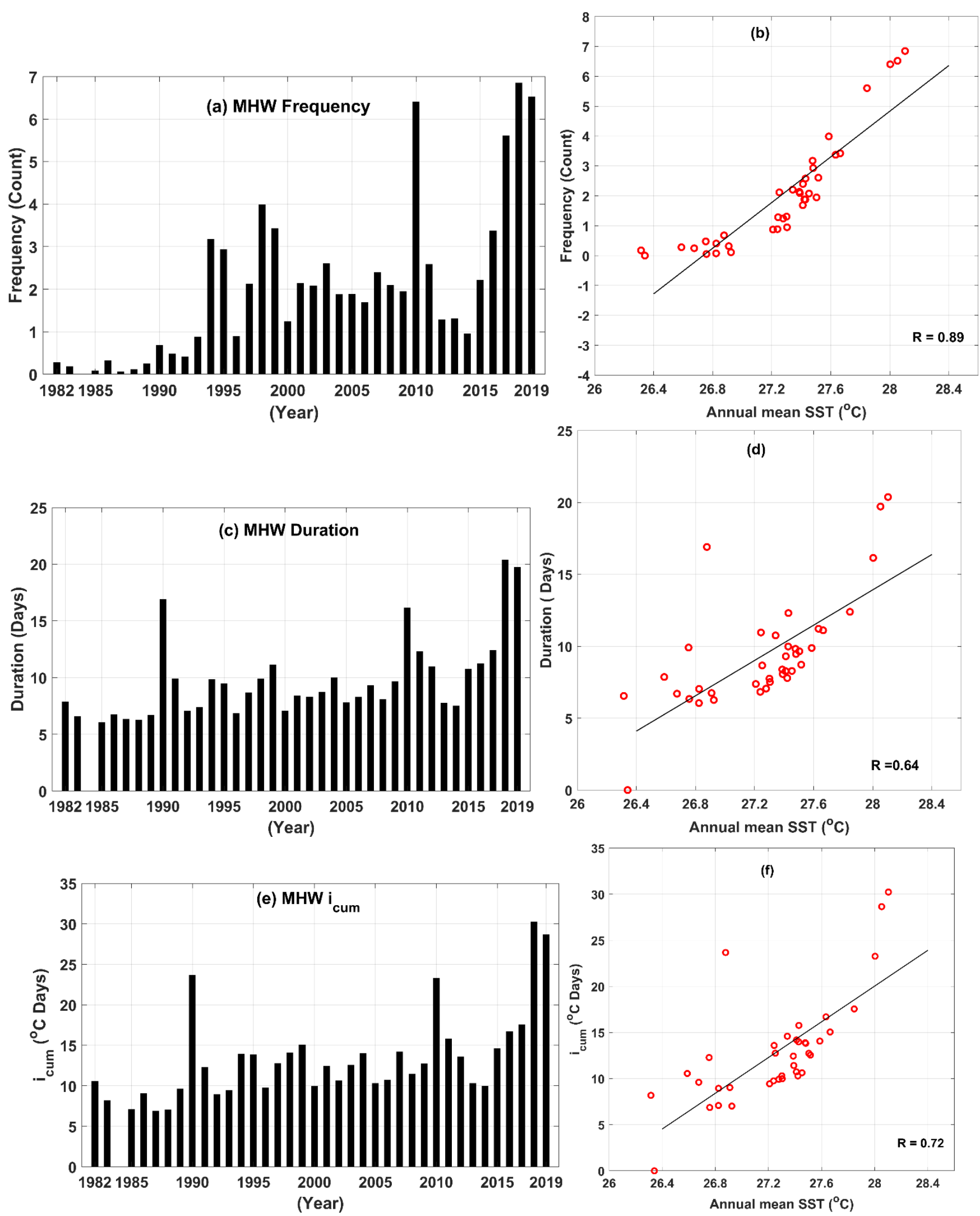

Figure 6. Bars of regional averaged annual means of the MHW (a) frequency, (c) duration, and (e) cumulative intensity $\left(\mathrm{i}_{\text {cum }}\right)$, and scatter plots of annual mean SST and MHW (b) frequency, (d) duration, and (f) cumulative intensity (i $\mathrm{i}_{\text {cum }}$ ), over the Red Sea over the period from 1982 to 2019, with the black lines representing the best-fit linear curve. 


\subsection{Examples of MHW Events}

In this section, we show two example MHW events discovered in our MHW analysis between 1982 and 2019. In terms of duration and $i_{\max }$, we chose two MHW events in 2019.

Table 1 shows examples of the Red Sea MHW event characteristics (mean duration, $\mathrm{i}_{\max }, \mathrm{i}_{\text {mean }}$, and $\mathrm{i}_{\text {cum }}$ ) over the study period (1982-2019) with the corresponding $\mathrm{MHW}_{\text {onset }}$ (start date), $\mathrm{MHW}_{\text {end }}$ (end date), and longitude and latitude.

Table 1. Examples of the Red Sea MHW event characteristics (mean duration (days), $\mathrm{i}_{\max }\left({ }^{\circ} \mathrm{C}\right), \mathrm{i}_{\text {mean }}\left({ }^{\circ} \mathrm{C}\right)$, and $\mathrm{i}_{\text {cum }}$ $\left({ }^{\circ} \mathrm{C}\right.$ days)) over the study period (1982-2019) with the corresponding $\mathrm{MHW}_{\text {onset, }} \mathrm{MHW}_{\text {end }}$, and longitude and latitude (in degrees).

\begin{tabular}{cccccccc}
\hline MHW $_{\text {onset }}$ & MHW $_{\text {end }}$ & Long $^{\circ} \mathbf{E}$ & Lat $^{\circ} \mathbf{N}$ & Mean Duration (Days) & $\mathbf{i}_{\text {max }}\left({ }^{\circ} \mathbf{C}\right)$ & $\mathbf{i}_{\text {mean }}\left({ }^{\circ} \mathbf{C}\right)$ & $\mathbf{i}_{\text {cum }}\left({ }^{\circ} \mathbf{C}\right.$ Days) \\
\hline 10 May 2019 & 31 December 2019 & 32.375 & 29.625 & 236 & 2.94 & 1.42 & 333.94 \\
\hline 17 May 2019 & 21 July 2019 & 37.875 & 20.175 & 66 & 4.21 & 2.15 & 142.06 \\
\hline
\end{tabular}

The long duration event ( 236 days) with $\mathrm{i}_{\text {cum }} 333.94{ }^{\circ} \mathrm{C}$ days was detected in the Gulf of Suez during the period from 10 May 2019 to 31 December 2019, with an $\mathrm{i}_{\max }$ of $2.94{ }^{\circ} \mathrm{C}$ and $\mathrm{i}_{\text {mean }}$ of $1.42{ }^{\circ} \mathrm{C}$ (Figure $\left.7 \mathrm{a}, \mathrm{b}\right)$. A high MHW $\mathrm{i}_{\max }$ event of $4.21^{\circ} \mathrm{C}$ was noticed in 2019 off the Sudanese coast (i.e., between $\sim$ lat $18.5^{\circ} \mathrm{E}$ and $20.2^{\circ} \mathrm{E}$ ) (Figure $7 \mathrm{c}, \mathrm{d}$ ) and lasted for 66 days (17 May-21 July) with an $i_{\text {mean }}$ of $2.15{ }^{\circ} \mathrm{C}$ and $i_{\text {cum }}$ of $142.06^{\circ} \mathrm{C}$ days.

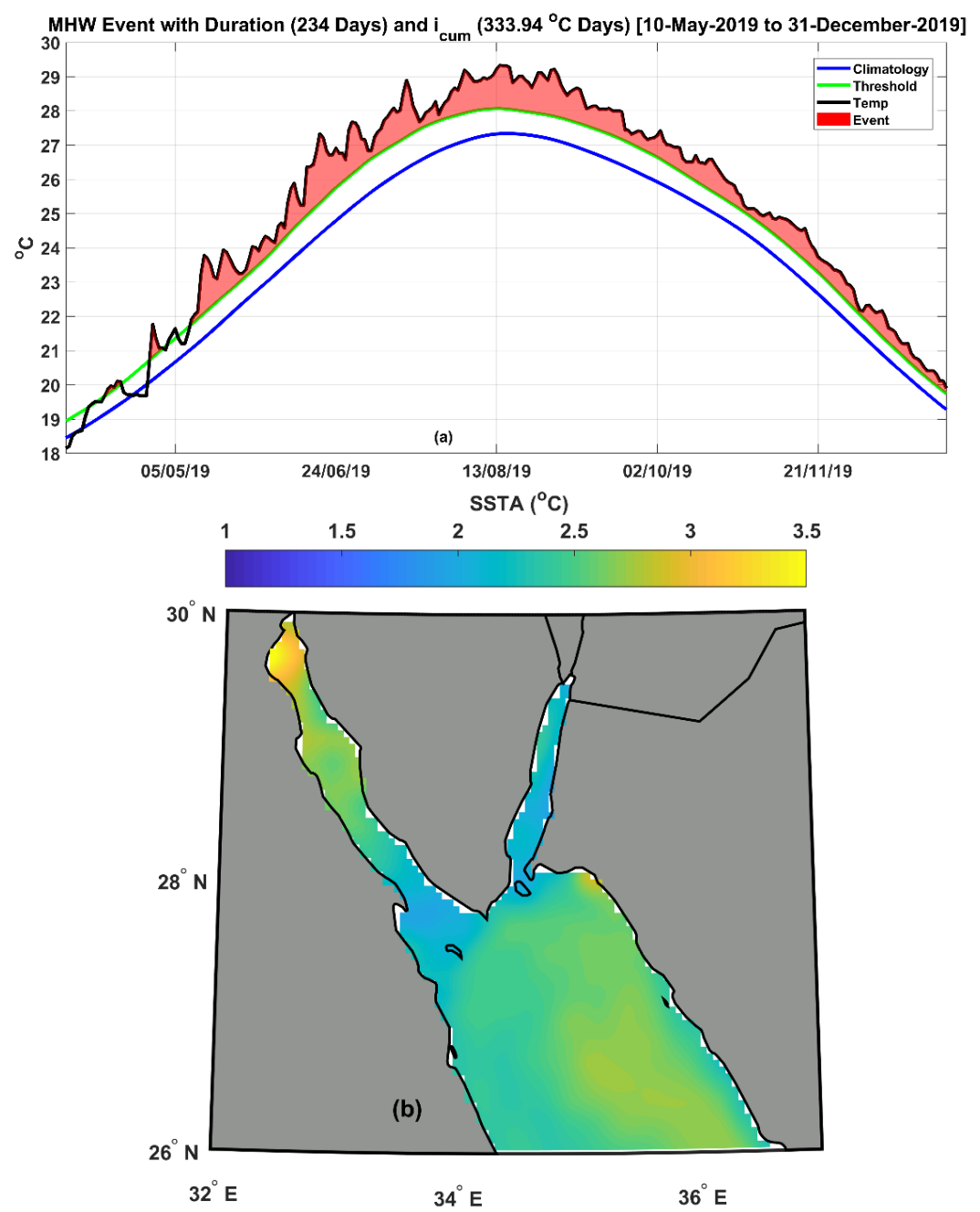

Figure 7. Cont. 

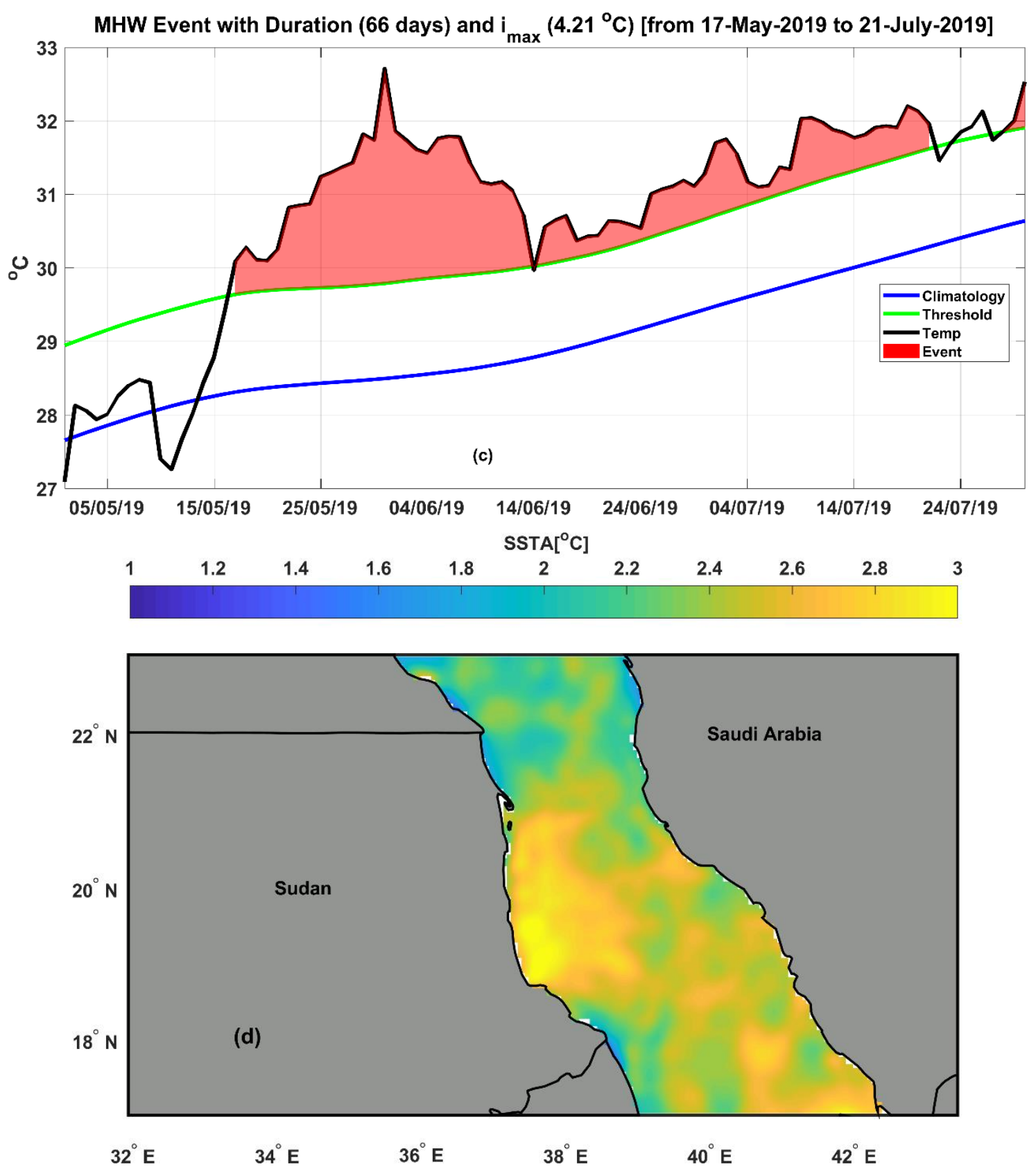

Figure 7. Examples of the Red Sea MHW events over the study period (1982-2019) chosen in the year 2019, The SST climatology from OSTIA SST for the detection of MHWs (blue color), 90th percentile MHW threshold (green color), and SST time series (black color) for each MHW. The area filled with pink color shows the period accompanied with the identified MHW. (a) MHW duration event (236 days) (10 May 2019 to 31 December 2019); (b) Spatial mean SST anomaly distribution ${ }^{\circ} \mathrm{C}$ (10 May 2019 to 31 December 2019); (c) MHW maximum intensity event (i $\left.\mathrm{i}_{\max } 4.21{ }^{\circ} \mathrm{C}\right)$ (17 May 2019-21 July 2019); (d) Spatial mean SST anomaly distribution ${ }^{\circ} \mathrm{C}$ (17 May 2019-21 July 2019).

\section{Discussion}

Regarding to our SST climatology and trends analysis (Figures 2 and 3), the highest temperatures $\left(>29^{\circ} \mathrm{C}\right.$, Figure 2a) were found in summer and early autumn. The lowest temperatures $\left(<25^{\circ} \mathrm{C}\right.$, Figure $\left.2 \mathrm{a}\right)$ were recorded in winter and early spring. We found the seasonal temperature difference between summer and winter to be approximately $6{ }^{\circ} \mathrm{C}$ (Figure 2a) in agreement with [22]. According to Figure 2b, the Red Sea temporal SST trend was approximately $0.32 \pm 0.03{ }^{\circ} \mathrm{C} /$ decade from 1982 to 2019 , which was higher than [26], possibly due to the use of longer time series and high-resolution OSTIA data. 
Many efforts have been made to investigate the Red Sea SST trends using NOAA OI SST coarse resolution data. The authors of [24] showed that August and February are the warmest and coolest months in the Red Sea, with a significant trend of $0.5{ }^{\circ} \mathrm{C}$ and $0.3{ }^{\circ} \mathrm{C} /$ decade, respectively. According to [15], the overall warming trend of the Red Sea maximum SST was approximately $0.17^{\circ} \mathrm{C} /$ decade, while the northern Red Sea alone warmed by between 0.4 and $0.45{ }^{\circ} \mathrm{C} /$ decade from 1982 to 2015 . The authors of [42] examined the warming of the Red Sea SST from 1982 to 2016 and found an intense warming trend of $0.29^{\circ} \mathrm{C} /$ decade. Recently, [26] demonstrated that the SST warming trend ranged from $0.1{ }^{\circ} \mathrm{C} /$ decade in the south to $0.4{ }^{\circ} \mathrm{C} /$ decade in the north Red Sea between 1982 and 2017. Our analysis revealed a high spatial variability of SST trends over the Red Sea (Figure 3) in the period from 1982 to 2019 , varying from 0.10 to $0.47^{\circ} \mathrm{C} /$ decade. The basin averaged warming rate was approximately $0.342 \pm 0.047^{\circ} \mathrm{C} /$ decade. The highest trend was found in the deep area of the Red Sea (i.e., depth > 1200 m), while lower values were found in the Gulf of Suez, the Gulf of Aqaba, and the southern part of the Red Sea.

The EOF analysis (Figure 4) indicated that the highest SST variability was found over the central and northern part of the Red Sea, while the lowest variability was found over the Gulfs of Suez and Aqaba, as well as the southernmost part of the Red Sea. This could be attributed to the persistence of monsoon winds from the Arabian Sea in the southern Red Sea and northwesterly winds from the Sinai Peninsula in the northern Red Sea [41].

In Figure 5, the authors investigated the mean and spatial trend of the main characteristics of MHWs (frequency, days, duration, and intensities) for the Red Sea over the study period (1982-2019). The maximum MHW frequency values of $>2$ counts were found in the coastal areas of Sudan, Eritrea, Yemen, and Saudi Arabia. The MHW frequency trend values were statistically significant $(p<0.05)$ over the whole Red Sea. According to Figures 1 and $5 b$, the deep area (i.e., depth $>1000 \mathrm{~m}$ ) between Eritrea and the south coast of Saudi Arabia has the highest MHW frequency trend ( $>1.8$ counts/decade). The MHW total days' spatial patterns (Figure 5c) show maximum values of more than 25 days in the Gulfs of Suez and Aqaba. This may be due to the fact that the Gulfs of Suez and Aqaba are well resolved using high-resolution OSTIA data. Figure $5 b$,d show a similarity among the $p$-values between the MHW frequency and total days trend fields. We found the maximum MHW duration spatial trend significant values $(p<0.05 ;>8$ days/decade) to be in the middle of the Red Sea (i.e., between $\sim$ lat $18^{\circ} \mathrm{E}$ and $21^{\circ} \mathrm{E}$ ), as demonstrated by Figure 5f. Maximum MHW $\mathrm{i}_{\text {cum }}$ values of $>22\left({ }^{\circ} \mathrm{C}\right.$ days) were found in the northern Red Sea, excluding the Gulfs of Suez and Aqaba (i.e., between lat $22^{\circ} \mathrm{E}$ and $28^{\circ} \mathrm{E}$ ) (Figure $5 \mathrm{~g}$ ). The MHW $\mathrm{i}_{\max }$ shows high values $\left(>1.8^{\circ} \mathrm{C}\right)$ throughout most of the Red Sea (Figure 5i), with the exception of the southernmost part near Bab El-Mandab. The MHW matrices for the Red Sea region show a clear ascending trend over the last decade (Figure 6). The highest annual MHW duration and $\mathrm{i}_{\text {cum }}$ were found during the year 2018 ( 21 days and $30^{\circ} \mathrm{C}$ days). The correlation coefficients between the annual mean SST, MHW duration, and $\mathrm{MHW} \mathrm{i}_{\text {cum }}$ were 0.64 and 0.72 , respectively.

The MHW duration event of 236 days was detected in the Gulf of Suez in 2019 from 10 May 2019 to 31 December 2019 (Figure 7a,b). The high MHW $\mathrm{i}_{\max }$ event of $4.21^{\circ} \mathrm{C}$ was discovered in May 2019 off the Sudanese coast (i.e., between $\sim$ lat $18.5^{\circ} \mathrm{E}$ and $20.2^{\circ} \mathrm{E}$ ), (Figure 7c,d).

\section{Conclusions}

This study provides a comprehensive analysis of SST variability, trends, and spatiotemporal patterns of marine heat waves in the Red Sea from 1982 to 2019. To the authors' knowledge, this is the first study to examine marine heat waves and SST trends in the Red Sea using high-resolution data. A statistically significant SST trend was observed over the Red Sea. The EOF analysis showed that the highest interannual variability was detected over the central and northern part of the Red Sea, while the lowest variability was found over the Gulfs of Suez and Aqaba and the southernmost part of the Red Sea. 
We found that all MHW characteristic (frequency, duration, and cumulative intensity $\left.\left(\mathrm{i}_{\text {cum }}\right)\right)$ trends increased over the study period. The highest annual MHW frequencies were detected in the years 2018, 2019, 2010, and 2017. There were no MHWs found during the year 1984. A strong correlation was found between the annual MHW frequency and the annual mean SST. Over the period from 2000 to 2019, we discovered that the average MHW frequency and duration increased by $35 \%$ and $67 \%$, respectively. Further research is needed to investigate the causes of MHWs and their effects on marine life in the Red Sea. We believe that our study is just the beginning of a series of studies on this hot topic.

Author Contributions: Conceptualization, O.I., B.M. and H.N.; methodology, H.N., B.M. and O.I.; formal analysis, O.I., H.N. and B.M.; investigation, O.I., B.M. and H.N.; resources, B.M., O.I. and H.N.; data curation, B.M., H.N. and O.I.; writing-original draft preparation, O.I., B.M. and H.N.; writing-review and editing, H.N., O.I. and B.M.; visualization, B.M., O.I. and H.N.; supervision, H.N., B.M. and O.I. All authors have read and agreed to the published version of the manuscript.

Funding: This research received no external funding.

Institutional Review Board Statement: Not applicable.

Informed Consent Statement: Not applicable.

Data Availability Statement: Not applicable.

Acknowledgments: The authors would like to express their appreciation to the two anonymous reviewers for their constructive comments.

Conflicts of Interest: The authors declare no conflict of interest.

\section{References}

1. Selig, E.R.; Casey, K.S.; Bruno, J.F. New insights into global patterns of ocean temperature anomalies: Implications for coral reef health and management. Glob. Ecol. Biogeogr. 2010, 19, 397-411. [CrossRef]

2. Frölicher, T.L.; Laufkötter, C. Emerging risks from marine heat waves. Nat. Commun. 2018, 9, 1-4. [CrossRef]

3. Smale, D.A.; Wernberg, T.; Oliver, E.C.J.; Thomsen, M.; Harvey, B.P.; Straub, S.C.; Burrows, M.T.; Alexander, L.V.; Benthuysen, J.A.; Donat, M.G.; et al. Marine heatwaves threaten global biodiversity and the provision of ecosystem services. Nat. Clim. Chang. 2019, 9, 306-312. [CrossRef]

4. Li, Y.; Ren, G.; Wang, Q.; You, Q. More extreme marine heatwaves in the China Seas during the global warming hiatus. Environ. Res. Lett. 2019, 14, 104010. [CrossRef]

5. Hobday, A.J.; Alexander, L.V.; Perkins, S.E.; Smale, D.A.; Straub, S.C.; Oliver, E.C.J.; Benthuysen, J.A.; Burrows, M.T.; Donat, M.G.; Feng, M.; et al. A hierarchical approach to defining marine heatwaves. Prog. Oceanogr. 2016, 141, 227-238. [CrossRef]

6. Hobday, A.J.; Oliver, E.C.J.; Gupta, A.S.; Benthuysen, J.A.; Burrows, M.T.; Donat, M.G.; Holbrook, N.J.; Moore, P.J.; Thomsen, M.S.; Wernberg, T.; et al. Categorizing and naming marine heatwaves. Oceanography 2018, 31, 162-173. [CrossRef]

7. Ibrahim, O.; Mohamed, B.; Nagy, H. Spatial Variability and Trends of Marine Heat Waves in the Eastern Mediterranean Sea over 39 Years. J. Mar. Sci. Eng. 2021, 9, 643. [CrossRef]

8. Barale, V. The African Marginal and Enclosed Seas: An Overview. Remote Sens. Afr. Seas Springer Neth. 2014, 3-29. [CrossRef]

9. Hoteit, I.; Abualnaja, Y.; Afzal, S.; Ait-El-Fquih, B.; Akylas, T.; Antony, C.; Dawson, C.; Asfahani, K.; Brewin, R.J.; Cavaleri, L.; et al. Towards an end-to-end analysis and prediction system for weather, climate, and Marine applications in the Red Sea. Bull. Am. Meteorol. Soc. 2021, 102, E99-E122. [CrossRef]

10. Al-Horani, F.A.; Al-Rousan, S.A.; Al-Zibdeh, M.; Khalaf, M.A. The status of coral reefs on the jordanian coast of the gulf of aqaba, red sea. Zool. Middle East 2006, 38, 99-110. [CrossRef]

11. Eladawy, A.; Nadaoka, K.; Negm, A.; Abdel-Fattah, S.; Hanafy, M.; Shaltout, M. Characterization of the northern Red Sea's oceanic features with remote sensing data and outputs from a global circulation model. Oceanologia 2017, 59, 213-237. [CrossRef]

12. Sofianos, S.S.; Johns, W.E.; Murray, S.P. Heat and freshwater budgets in the Red Sea from direct observations at Bab el Mandeb. Deep. Res. Part II Top. Stud. Oceanogr. 2002, 49, 1323-1340. [CrossRef]

13. Johns, W.E.; Sofianos, S.S. Atmospherically forced exchange through the Bab El Mandeb strait. J. Phys. Oceanogr. 2012, 42, 1143-1157. [CrossRef]

14. Zarokanellos, N.D.; Papadopoulos, V.P.; Sofianos, S.S.; Jones, B.H. Physical and biological characteristics of the winter-summer transition in the Central Red Sea. J. Geophys. Res. Ocean. 2017, 122, 6355-6370. [CrossRef]

15. Chaidez, V.; Dreano, D.; Agusti, S.; Duarte, C.M.; Hoteit, I. Decadal trends in Red Sea maximum surface temperature. Sci. Rep. 2017, 7, 8144. [CrossRef]

16. Patzert, W.C. Wind-induced reversal in Red Sea circulation. Deep Sea Res. Oceanogr. Abstr. 1974, 21, 109-121. [CrossRef]

17. Sofianos, S.S.; Johns, W.E. Observations of the summer Red Sea circulation. J. Geophys. Res. Ocean. 2007, 112. [CrossRef] 
18. Sofianos, S.; Papadopoulos, V.P.; Abualnaja, Y. Investigating the Interannual Variability of the Circulation and Water Mass Formation in the Red Sea. 2014. Available online: https://ui.adsabs.harvard.edu/abs/2014AGUFMOS51A0952S/abstract (accessed on 3 August 2021).

19. Cantin, N.E.; Cohen, A.L.; Karnauskas, K.B.; Tarrant, A.M.; McCorkle, D.C. Ocean warming slows coral growth in the central Red Sea. Science 2010, 329, 322-325. [CrossRef]

20. Karnauskas, K.B.; Jones, B.H. The Interannual Variability of Sea Surface Temperature in the Red Sea From 35 Years of Satellite and In Situ Observations. J. Geophys. Res. Ocean. 2018, 123, 5824-5841. [CrossRef]

21. Raitsos, D.E.; Hoteit, I.; Prihartato, P.K.; Chronis, T.; Triantafyllou, G.; Abualnaja, Y. Abrupt warming of the Red Sea. Geophys. Res. Lett. 2011, 38, 14601. [CrossRef]

22. Berman, T.; Paldor, N.; Brenner, S. Annual SST cycle in the Eastern Mediterranean, Red Sea and Gulf of Elat. Geophys. Res. Lett. 2003, 30, 1261. [CrossRef]

23. Osman, E.O.; Smith, D.J.; Ziegler, M.; Kürten, B.; Conrad, C.; El-Haddad, K.M.; Voolstra, C.R.; Suggett, D.J. Thermal refugia against coral bleaching throughout the northern Red Sea. Glob. Chang. Biol. 2018, 24, e474-e484. [CrossRef]

24. Hoegh-Guldberg, O.; Cai, R.; Poloczanska, E.S.; Brewer, P.G.; Sundby, S.; Hilmi, K.; Fabry, V.J.; Jung, S.; Perry, I.; Richardson, A.J.; et al. SM30-1 30 The Ocean Supplementary Material Coordinating Lead Authors: Lead Authors: Review Editors: To the Fifth Assessment Report of the Intergovernmental Panel on Climate Change; IPCC: Geneva, Switzerland, 2014; ISBN 9789291691432.

25. Alawad, K.A.; Al-Subhi, A.M.; Alsaafani, M.A.; Alraddadi, T.M. Atmospheric forcing of the high and low extremes in the sea surface temperature over the Red Sea and associated chlorophyll-a concentration. Remote Sens. 2020, 12, 2227. [CrossRef]

26. Shaltout, M. Recent sea surface temperature trends and future scenarios for the Red Sea. Oceanologia 2019, 61, 484-504. [CrossRef]

27. Papadopoulos, V.P.; Zhan, P.; Sofianos, S.S.; Raitsos, D.E.; Qurban, M.; Abualnaja, Y.; Bower, A.; Kontoyiannis, H.; Pavlidou, A.; Asharaf, T.T.M.; et al. Factors governing the deep ventilation of the Red Sea. J. Geophys. Res. Ocean. 2015, 120, 7493-7505. [CrossRef]

28. Good, S.; Fiedler, E.; Mao, C.; Martin, M.J.; Maycock, A.; Reid, R.; Roberts-Jones, J.; Searle, T.; Waters, J.; While, J.; et al. The current configuration of the OSTIA system for operational production of foundation sea surface temperature and ice concentration analyses. Remote Sens. 2020, 12, 720. [CrossRef]

29. Fiedler, S.; Crueger, T.; D'Agostino, R.; Peters, K.; Becker, T.; Leutwyler, D.; Paccini, L.; Burdanowitz, J.; Buehler, S.A.; Cortes, A.U.; et al. Simulated tropical precipitation assessed across three major phases of the coupled model intercomparison project (CMIP). Mon. Weather Rev. 2020, 148, 3653-3680. [CrossRef]

30. Thomson, R.E.; Emery, W.J. Data Analysis Methods in Physical Oceanography, 3rd ed.; Elsevier Inc.: Amsterdam, The Netherlands, 2014; ISBN 9780123877833.

31. Fenoglio-Marc, L.; Schöne, T.; Illigner, J.; Becker, M.; Manurung, P. Khafid Sea Level Change and Vertical Motion from Satellite Altimetry, Tide Gauges and GPS in the Indonesian Region. Mar. Geod. 2012, 35, 137-150. [CrossRef]

32. Mohamed, B.; Mohamed, A.; Alam El-Din, K.; Nagy, H.; Elsherbiny, A. Sea level changes and vertical land motion from altimetry and tide gauges in the Southern Levantine Basin. J. Geodyn. 2019, 128, 1-10. [CrossRef]

33. Skliris, N.; Sofianos, S.; Gkanasos, A.; Mantziafou, A.; Vervatis, V.; Axaopoulos, P.; Lascaratos, A. Decadal scale variability of sea surface temperature in the Mediterranean Sea in relation to atmospheric variability. Ocean Dyn. 2011, 62, 13-30. [CrossRef]

34. Wilks, D.S. Statistical Methods in the Atmospheric Sciences; Academic Press: Cambridge, MA, USA, 2011 ; ISBN 0123850223.

35. Hamed, K.H.; Ramachandra Rao, A. A modified Mann-Kendall trend test for autocorrelated data. J. Hydrol. 1998, 204, 182-196. [CrossRef]

36. Wang, F.; Shao, W.; Yu, H.; Kan, G.; He, X.; Zhang, D.; Ren, M.; Wang, G. Re-evaluation of the Power of the Mann-Kendall Test for Detecting Monotonic Trends in Hydrometeorological Time Series. Front. Earth Sci. 2020, 8, 14. [CrossRef]

37. Mohamed, B.; Abdallah, A.M.; Alam El-Din, K.; Nagy, H.; Shaltout, M. Inter-Annual Variability and Trends of Sea Level and Sea Surface Temperature in the Mediterranean Sea over the Last 25 Years. Pure Appl. Geophys. 2019, 176, 3787-3810. [CrossRef]

38. Zhao, Z.; Marin, M. A MATLAB toolbox to detect and analyze marine heatwaves. J. Open Source Softw. 2019, 4, 1124. [CrossRef]

39. Darmaraki, S.; Somot, S.; Sevault, F.; Nabat, P.; Cabos Narvaez, W.D.; Cavicchia, L.; Djurdjevic, V.; Li, L.; Sannino, G.; Sein, D.V. Future evolution of Marine Heatwaves in the Mediterranean Sea. Clim. Dyn. 2019, 53, 1371-1392. [CrossRef]

40. Oliver, E.C.J.; Donat, M.G.; Burrows, M.T.; Moore, P.J.; Smale, D.A.; Alexander, L.V.; Benthuysen, J.A.; Feng, M.; Sen Gupta, A.; Hobday, A.J.; et al. Longer and more frequent marine heatwaves over the past century. Nat. Commun. 2018, 9, 1-12. [CrossRef] [PubMed]

41. Langodan, S.; Cavaleri, L.; Vishwanadhapalli, Y.; Pomaro, A.; Bertotti, L.; Hoteit, I. The climatology of the Red Sea-Part 1: The wind. Int. J. Climatol. 2017, 37, 4509-4517. [CrossRef]

42. Alawad, K.A.; Al-Subhi, A.M.; Alsaafani, M.A.; Alraddadi, T.M. Decadal variability and recent summer warming amplification of the sea surface temperature in the Red Sea. PLoS ONE 2020, 15, e0237436. [CrossRef] 